\title{
The Floodplain Index - a new approach for assessing the ecological status of river/floodplain-systems according to the EU Water Framework Directive
}

\author{
Andreas Chovanec ${ }^{1}$, Johann Waringer ${ }^{2}$, Michael Straif ${ }^{3}$, Wolfram Graf ${ }^{3}$, Walter \\ Reckendorfer ${ }^{2}$, Andrea Waringer-Löschenkohl ${ }^{2}$, Herwig Waidbacher ${ }^{3}$ and Heike Schultz ${ }^{2}$
}

Keywords: Water Framework Directive, bioindication, floodplains

\section{Introduction}

During the last two decades theoretical and applied limnological research increasingly focused on the investigation of floodplain rivers (Amoros \& Roux 1988, Junk et al. 1989, Schiemer 1999, Ward et al. 1999, Findlay et al. 2002). Ecological key prerequisites of such systems are natural fluvial dynamics leading to flood-controlled disturbances, thereby favouring geomorphic processes and successional patterns (e.g. Amoros and Roux, 1988; Junk et al., 1989). A great variety of human activities has led to the longitudinal and lateral fragmentation of large river systems, which is considered to be one of the major threats to running water ecosystems (Dynesius and Nilsson, 1994; Schiemer, 1999). According to the requirements of the EU Water Framework Directive (WFD, 2000/60/EC; European Commission 2000), all surface water bodies should reach at least "good ecological status" (class II within a five class system). In line with the WFD, schemes for assessing the ecological status of floodplain areas were developed for dragonflies (Chovanec \& Waringer 2001; Chovanec et al. 2004) and caddisflies (Waringer \& Graf 2002). Based on these methods, a multi-species approach is presented including a comprehensive set of indicator groups, which allow to thoroughly explore connectivity patterns of a river-floodplain system: molluscs, caddisflies, dragonflies, amphibians and fish. The assessment procedure was developed for a large, anabranched river system, the Danube in Austria, and tested in a floodplain area of this river upstream of Vienna.

\section{Methods}

In order to describe the species' habitat preferences numerically, 10 valency points were distributed among five habitat types $(\mathrm{H} 1-\mathrm{H} 5$; $\mathrm{H} 1$ : eupotamic, that is high connectivity between floodplain waterbody and main river, H5: temporary waterbody; Fig. 1). Speciesspecific habitat values (HV) were calculated according to the equation:

$\mathrm{HV}=(1 * \mathrm{H} 1+2 * \mathrm{H} 2+3 * \mathrm{H} 3+4 * \mathrm{H} 4+5 * \mathrm{H} 5) / 10$.

Indication weights ranging from 1 for eurytopic species to 5 for stenotopic species have been allocated to each species in order to identify sensitive species (indication weight $>3$ ). The allocation of the indication weights was carried out according to the scheme of Sladecek (1964). The valency point distributions are based on autecological knowledge as well as literature data.

\footnotetext{
${ }^{1}$ Federal Environment Agency, Spittelauer Lände 5, A-1090 Vienna, Austria

${ }^{2}$ University of Vienna, Department of Freshwater Ecology, Althanstraße 14, A-1090 Vienna, Austria

${ }^{3}$ University of Natural Resources and Applied Life Sciences, Department Hydrobiology, Max Emanuel-Straße 17, A-1180 Vienna, Austria
} 


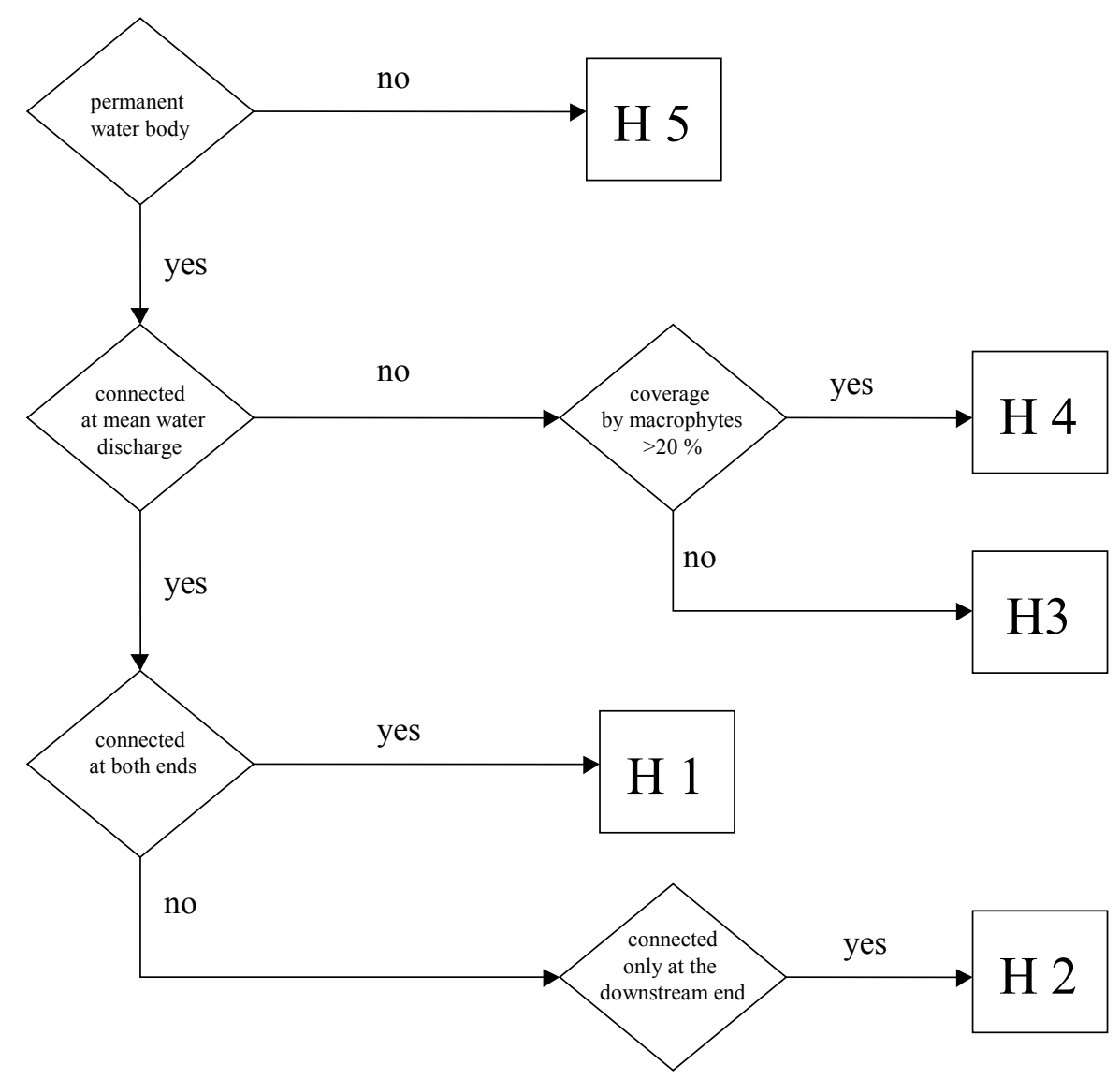

Fig. 1. Flow chart for the differentiation of the habitat types.

The Floodplain Index (FI) is based on the summation of the habitat values and indication weights of all species present at the sampling site and is calculated using the following equation:

$\mathrm{FI}=\Sigma(\mathrm{HV} * \mathrm{IW}) / \Sigma \mathrm{IW}$

where $\mathrm{HV}$ is the habitat value and IW is the species-specific indication weight (examples are given in Table 1). The method is based on a presence / absence approach; thus, abundances are not considered in the formula.

The calculation of the index is made for every investigation site and results in a number between 1 and 5 , indicating habitat preferences of the community at the investigation site. When comparing the percentage distribution of calculated habitat types $\mathrm{H} 1-\mathrm{H} 5$ with the percentage of the study area's reference situation, deviations may be transformed into the five quality classes of the Water Framework Directive. For the Austrian Danube (reference situation= pristine anabranched river section) this transformation is done as follows:

- Quality class I: Distribution and range of the FI correspond to the reference situation and indicate that all habitat types are present with $\mathrm{H} 1$ dominating.

- Quality class II: Distribution and range of the FI indicate that all habitat types are present with $\mathrm{H} 1$ not dominating or one habitat type (with the exception of $\mathrm{H} 1$ ) is missing.

- Quality class III: Distribution and range of the FI indicate that at least H1 or two habitat types are missing.

- Quality class IV: Distribution and range of the FI indicate that one or two habitat types are present; few sensitive species are found. 
- Quality class V: Floodplain is missing or distribution and range of the FI indicate that only one habitat type is found; no or nearly no sensitive species are found.

\section{Results and discussion}

Investigations were carried out in a floodplain area of the Danube at Klosterneuburg. The former pristine type of the Danube in this area was an anabranched river system characterised by hydrologically dynamic side arms, vegetated islands and gravel bars. Before the major regulation of the Danube (1870 to 1875$)$, the main river channels were located only a short distance from the city of Klosterneuburg. The width of the active corridor of the Danube at this time averaged about $1500 \mathrm{~m}$. Before the major regulation, one big side arm of the Danube was close to the monastery of Klosterneuburg at the western border of an area which nowadays is called "Klosterneuburger Durchstich".

Table 1. Examples of indicator species (Mollusca, Odonata, Trichoptera, Amphibia, Pisces) of the river/floodplain systems of the Austrian Danube considered in the Floodplain Index. H15: habitat types, HV: habitat values, IW: indication weights.

H1 H2 H3 H4 H5 HV IW

Acroloxus lacustris (LINNAEUS, 1758)

Lestes sponsa (HANSEMANN, 1823)

Agapetus delicatulus MCLACHLAN, 1884

Triturus dobrogicus (KIRITZESCU, 1903)

Gymnocephalus cernuus (Linnaeus, 1758)

\begin{tabular}{|c|c|c|c|c|}
\hline \multirow{3}{*}{1} & 4 & 6 & & 3,6 \\
\hline & 4 & 4 & 1 & 3,5 \\
\hline & & & & 1 \\
\hline & 1 & 2 & 7 & 4,6 \\
\hline 3 & 5 & 1 & & 2,6 \\
\hline
\end{tabular}

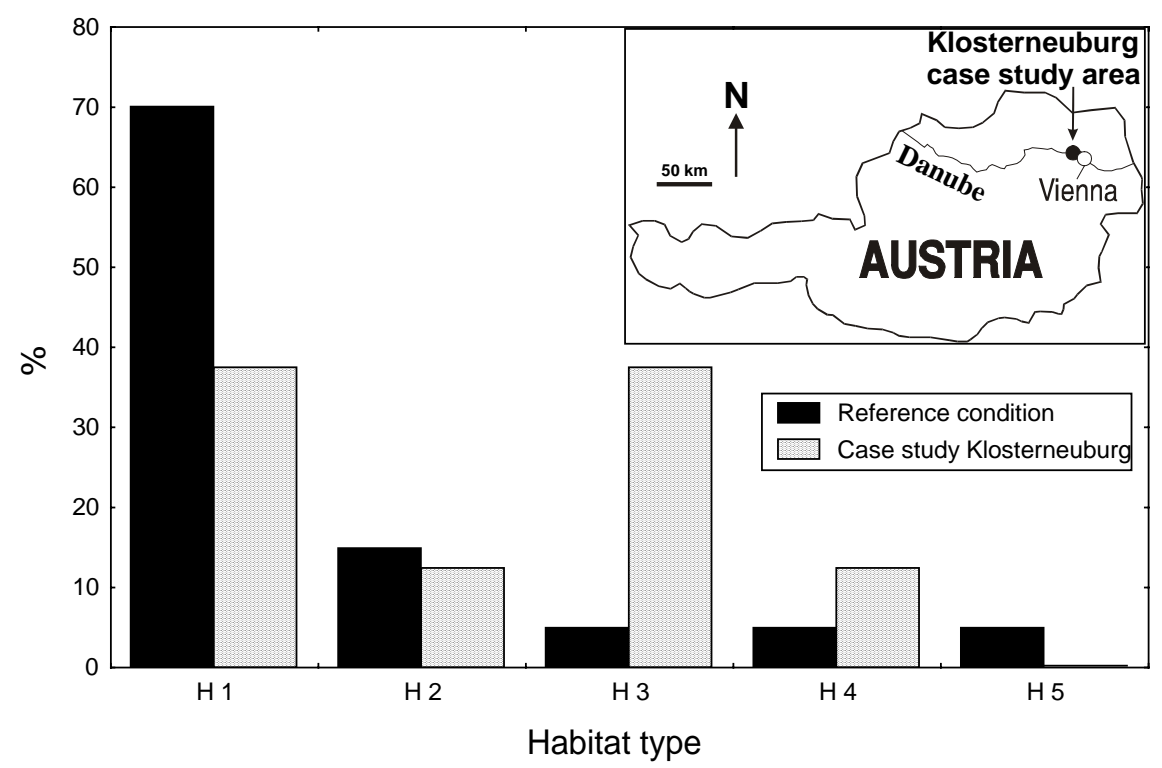

Fig. 2. Results of the case study at Klosterneuburg (dotted bars), indicating good ecological status; pristine anabranched river section of the Danube: black bars. Upper right insert: location of the study area in Austria.

For the study, 8 representative investigation sites were selected; 6 of them were $100 \mathrm{~m}$ stretches situated at large water bodies, 2 of them were small water bodies investigated in toto. Field work was performed in 2002 according to the methods described above. Fig. 2 
shows the comparison between the proportion of habitat types in a former pristine anabranched river section of the Danube and in the Klosterneuburg case study area: The area is characterised by a high proportion of the habitat types $\mathrm{H} 1$ and $\mathrm{H} 3$, but $\mathrm{H} 1$ is not dominating. Habitat types typical of strong terrestrialisation processes (H4) play only a minor role or are missing (H5). According to the description of status classes given above, the study area is ranked as class II (good ecological status).

\section{References}

Amoros, C. \& Roux, A.L. (1988): Interaction between water bodies within the floodplains of large rivers: function and development of connectivity. - Münstersche Geographische Arbeiten 29: 125-130.

ChOVAnec, A. \& WARINGer, J. (2001): Ecological integrity of river/floodplain-systems assessment by dragonfly surveys. - Regulated Rivers: Research \& Management 17: 493-507.

Chovanec, A., Waringer, J., RaAB, R. \& LAister, G. (2004): Lateral connectivity of a fragmented large river system: assessment on a macroscale by dragonfly surveys (Insecta: Odonata). - Aquatic Conservation: Marine and Freshwater Ecosystems 14: 163-178.

DyNeSIUS, M. \& NiLSSON, C. (1994): Fragmentation and flow regulation of river systems in the northern third of the world. - Science 266: 753-762.

Findlay, E.G., Kiviat, E., NiEdER, W.C. \& Blair, E.A. (2002): Functional assessment of a reference wetland set as a tool for science, management and restoration. - Aquatic Sciences 64: 107-117.

JUnK, W.J., BAYLEY, P.B. \& SPARKS, R.E. (1989): The flood pulse concept in river floodplain systems.- Canad. Journal of Fisheries and Aquat. Sci. 106: 110-127.

SCHIEMER, F. (1999): Conservation of biodiversity in floodplain rivers. - Archiv für Hydrobiologie, Supplement 115 Large Rivers 11: 423-438.

SLADECEK, V. (1964): Zur Ermittlung des Indikations-Gewichtes in der biologischen Gewässeruntersuchung. - Arch. Hydrobiol. 60: 241-243.

WARD, J.V., TOCKNER, K. \& SCHIEMER, F. (1999): Biodiversity of floodplain river ecosystems: ecotones and connectivity. - Regulated Rivers: Research \& Management 15: 125-139.

WARINGER, J. \& GRAF, W. (2002): Trichoptera communities as a tool for assessing the ecological integrity of Danubian floodplains in Lower Austria.- Proc. of $10^{\text {th }}$ International Symosium on Trichoptera, Nova Suppl. Ent.: 617-625. 